\title{
Affective radicality: prisons, Palestine, and interactive documentary
}

\section{Ryan Watson}

To cite this article: Ryan Watson (2017) Affective radicality: prisons, Palestine, and interactive documentary, Feminist Media Studies, 17:4, 600-615, DOI: 10.1080/14680777.2017.1326560

To link to this article: http://dx.doi.org/10.1080/14680777.2017.1326560

曲 Published online: 05 Jun 2017.

Submit your article to this journal $\llbracket$

Џll Article views: 49

Q View related articles $\sqsubset$

View Crossmark data 


\title{
Affective radicality: prisons, Palestine, and interactive documentary
}

\author{
Ryan Watson \\ Department of Fine Arts, Misericordia University, Dallas, PA, USA
}

\begin{abstract}
This essay analyzes two recent interactive documentary projects: Sharon Daniel's Public Secrets (2006), an exploration of the prison industrial complex through the testimonies of female inmates in California, and Zohar Kfir's Points of View (2014) which "maps" Palestinian video advocacy projects made for and/or disseminated by $\mathrm{B}^{\prime} T$ selem, a human rights organization working in the occupied territories. I argue that the interactive documentary form, as deployed by Daniel and Kfir, draws on the legacies of radical documentary practice, but offers new possibilities for engagement and intervention. The interactive documentary form functions as a structuring device for a wealth of affectively powerful witnesses, testimonies, and varied forms of evidence. This essay explores how interactive documentaries allow viewers/users a multi-faceted affective encounter with a range of subjects and evidence. This form, in concert with a radical political stance, I argue, is a locus for the representation of and viewer/user critical engagement with broad systemic problems, renders visible hidden structures of violence and power, and engenders an "affective radicality" that moves viewers/users into larger networks of political discourse, militant activism, and practices of resistance.
\end{abstract}

\section{KEYWORDS}

Affect; interactive documentary; Palestine; prison; radicality

Since its inception, documentary film has been uniquely affiliated with political movements, revolutions, and demands for social change. The most militant strain of this tendency was dubbed the radical or "committed" documentary (Thomas Waugh 1984, xiv), and its lineage encompasses the work of Jean Vigo, Dziga Vertov, Joris Ivens, and various workers' collectives, through the multiple manifestations of radical documentary in the 1960s and 1970s, particularly Third Cinema, into the 1980s and 1990s with the rise of video activism associated with feminist, anti-racist, and LGBTQ causes. From Dziga Vertov's (1926 [1984], 58-60) wish for a "factory of facts" to the term "visible evidence" (Jane Gaines and Michael Renov 1999) coined after the wide dissemination of the Rodney King tape, radical documentarians have had, as a fundamental basis of their work, a concern with the illumination of the usually "unseen," and the strategic uses of witnesses, testimonies, archives, and evidence. This is coupled with the will to give access to representation for marginalized groups in the cause of global collectivity and exchange. These objectives are underscored by a constant openness 
to experimentation with new forms and technologies, as well as with a militant political and/ or ideological stance.

All of the aforementioned objectives and inclinations have been made manifest or accelerated with the rise of new media technologies and digital networks. Technological developments, vast digital storage capability, and a plethora of cameras have led to a mass of witnesses and countless hours of filmic evidence. To succeed in advocating for a particular cause, today's radical documentarians must present their collected evidence tactically and strategically, employing the logic of amassing as a radical intervention. This essay explores how the interactive documentary form allows viewers/users a multi-faceted affective encounter with a range of subjects and evidence. This form, in concert with a radical political stance, I argue, is a locus for the representation of and viewer/user critical engagement with broad systemic problems, renders visible hidden structures of violence and power, and engenders an "affective radicality" that moves viewers/users into larger networks of political discourse, militant activism, and practices of resistance.

I consider two recent interactive documentary projects that examine the lives of women in prison in California and the Israeli occupation of Palestine, respectively. The first project I analyze, media artist Sharon Daniel's Public Secrets (2006), is an exploration of the prison industrial complex and the struggles of female inmates at the Central California Women's Facility (CCWF) in Chowchilla, CA, the largest female correctional facility in the United States. Public Secrets eschews the photographic (cameras are explicitly prohibited in the prison) relying instead on an effective mixture of sound, text, and minimal graphic design. The second project, Points of View (2014), was created by New York-based, Israeli video artist Zohar Kfir and maps the Palestinian video advocacy projects created for and/or disseminated by B'Tselem, an Israeli organization working on behalf of Palestinian rights in the occupied territories. ${ }^{1}$ Whereas Public Secrets eschews imagery, Points of View foregrounds conventionally shot, short documentary videos. I chose these particular projects because they engage with two seemingly intractable and urgent situations that are difficult to capture in their scope and complexity in traditional forms of documentary; they are made by female media artists - a group traditionally underrepresented in documentary studies; and because the occupation of Palestine and the prison industrial complex share a similar set of concerns.

Black feminist critics, most notably Angela Y. Davis, have recently explored the intersectional identities and attendant basis for global solidarity between the struggle of the Palestinian people and those incarcerated within the prison industrial complex. Davis contends:

... it's important to insist on the intersectionality of movements. In the abolition movement, we've been trying to find ways to talk about Palestine so that people who are attracted to a campaign to dismantle prisons in the US will also think about the need to end the occupation in Palestine. $(2016,21)$

The linkage is made particularly clear by Davis's investigation of G4S, a global "security" firm that is the world's third largest private corporation. Davis contends that, "G4S is especially important because it participates directly and blatantly in the maintenance and reproduction of repressive apparatuses in Palestine-prisons, checkpoints, the apartheid wall, to name a few ..." $(2016,57)$. Beyond Palestine, G4S, argues Davis, "characterizes the profit-driven motives of transnational corporations associated with the rise of mass incarceration in the US and the world" $(2016,59)$. The carceral structure of both occupation and the prison industrial complex is one of enclosure, partition, and exclusion composed of criminalized bodies. 
Like the voices of US prisoners and discussion of the prison industrial complex seen in Public Secrets, we rarely receive discussion in mainstream Western media about the Israeli occupation of Palestine and its stultifying effects on the lives of everyday Palestinian people. Kfir's Points of View, a title that speaks to both a diversity of opinion and various points on a map that the viewer/user is able to figuratively zoom-in to view, seeks to rectify this omission from public discourse.

Kfir's project intervenes on two registers. First, by disseminating the work of B'Tselem to a wider audience, thereby promoting their advocacy work while giving Palestinian voices and stories a global platform. Second, by accumulating and structuring years of affectively potent video evidence, testimony, and stories to present a view of the Israeli-Palestinian conflict as one of long-standing, systematic oppression on the part of Israel, rather than discrete conflicts and skirmishes that one might see in Western news accounts. In a similar spirit, Daniel's work gives a voice to incarcerated women who have a paucity of means for communicating with the outside world. She relies on a large corpus of audio-based testimonial accounts from inmates buttressed by philosophical, legal, and theoretical texts. The archive of testimonial accounts, much like in Kfir's project, makes a convincing case for systemic abuse while the addition of the texts aligns the women's experiences within a broader framework of human rights and political discourse. These projects participate in the traditions and aspirations of the radical documentary. However, they do so while engaging and deploying new forms of narrative arrangement and viewer/user engagement. Both Public Secrets and Points of View present a mass of evidence endowed with the depth of affect that seeks to move the viewer/user from the position of active engagement with the project (in a virtual space) to critical engagement with the situation itself (in an actual space) -in other words, to convert virtual engagement to real world activism.

\section{Interaction and affect}

The interaction and combination of documentary with new media is an emerging topic of research for scholars from a variety of fields. Yet, there is no consensus on what such a practice should be called. ${ }^{2}$ I use the term "interactive documentary" as it best conveys the changing relationship between documentary makers and their audience as well as the spirit of radical documentary practice that relies on interaction and critical engagement to further political and social change.

This new genre is "characterized by the presence of distinctive recurring elements, including intuitive menus, maps, timelines, video clips, hyperlinks, and direct connections to social networks" (Stefano Odorico 2011, 236). The interactive documentary functions as "crossmedia product" that engenders a non-linear viewer/user experience within a global, connected network of other users (Odorico 2011,241). It is not the case that every interactive documentary will contain all of these features, but all contain some of them. Hart Cohen offers a similar conception and addresses another important aspect: namely, the importance of the archive and database. Cohen contends that this form of documentary practice relies on "access to an archive or other sources of knowledge and information" whereby the documentary maker "is closer to a curator or designer" providing a structured, though open, experience for the viewer/user (Hart Cohen 2012, 328).

Such an open experience implies a high degree of interactivity, yet the simple promise that one can "interact" with a work of art does not automatically make it affective or effective. 
According to Brian Massumi, simply saying "'you may interact with the work' is not enough" $(2008,2)$. But, when interactive art "works" affectively and effectively on the viewer/user it can "take the situation as its 'object' ... [i]t can take a situation and potentially 'open' the interaction it affords" $(2008,13)$. This "openness" is particularly relevant to the projects examined in this essay, as the subjects and situations presented are precisely those of enclosure, where representation (self or otherwise) is severely curtailed. Massumi argues that "this is precisely what makes art political in its own way. It can push further ... beyond the limits of current framings ..." $(2008,14)$. In the interactive documentaries analyzed here, the current framings place criminalized bodies within carceral structures. Each project seeks to break down the current framings of crime and punishment to represent occupation and incarceration as unjustified, systemic problems of enclosure and hiddenness that can be more holistically rendered.

As Lev Manovich notes, technologies of representation have produced, over the last 150 years, "an unprecedented amount of media materials: photo archives, film libraries, audio archives ..." (2001, 35). While an earlier generation effectively weaponized the camera in the capture and dissemination of previously unseen images, unheard sounds, and unrepresented bodies, the task of the radical documentarians of today is to weaponize the aforementioned vast audiovisual, testimonial archive in the cause of social, political, and economic justice. ${ }^{3}$ Interactive documentaries function as archival interfaces: a guide to user experience as well as a structuring device for evidence, witnesses, and testimonies. The viewers/users of interactive documentary projects find a greater burden placed on their engagement: they must actively navigate through these projects, making decisions, synthesizing disparate information, and creating connections between multiple forms of media. The combination of interactivity, data visualization, mapping, and open-ended narratives employs interfaces that can be manipulated on a variety of screens in a multiplicity of settings. These dynamic possibilities for exhibition and reception re-imagine the idea of the public while challenging older models of documentary spectatorship. The viewer/user also brings their own experiences, interests, and proclivities to bear on a wealth of material. Thus, the notion of authorship is further challenged and expanded, as Daniel and Kfir encourage engagement with a heterogeneous array of voices, opinions, and theories, all of which have a claim to structuring the meaning of viewer/user experience.

In documentary studies, particularly with radical political documentaries, affective power is often tied to the concepts of indexicality and evidence. Jane Gaines argues that "indexical privilege contributes something to one of the forks of the radical cause-the evidence of material conditions" (Jane Gaines 2007, 13). To transform the world, then, would include a combination of aspiration (to transform) coupled with evidence of material conditions; and requires a receiver of some sort to see, hear, and engage with these claims. The evidence presented seeks allies, collaborators, and potential militants. Thus, the realism of documentary relies on the capture of a certain kind of fact - what Gaines calls a "pathos of fact" (Jane Gaines 1999, 92). This sort of fact relies on the generation and reception of affect for its impact, but in Gaines' formulation it is limited to the unfolding of information, images, and narrative in the traditional documentary form. Yet, as Adrian Miles argues in regard to interactive documentary, the reception of these "pathos of fact" can lead to a type of "affective knowing" which "allows for the agency of knowledge that is documentary's currency" (2014, 80). He aligns the interactive documentary within the tripartite structure of perception (the user notices the images, sounds etc.), affect (the user is moved to decide), action (the user 
clicks to explore more). The affective and effective "quality" of the viewer/user experience is thus rooted in the "depth of material that is to be found" in a given project (Miles 2014, 80). Affect, in his formulation, is premised on a virtual encounter between subjects/information and the viewer/user that moves beyond the passivity and collectivity of traditional cinematic viewing to one of activity on the part of the viewer/user within a singular experience in front of a "deep" screen interface consisting of a superfluity of data, stories, and possible experiences. In interactive documentaries that critically engage with radical political movements, the impact of the evidence presented, both affective and effective, is amplified due to its vast accumulation and can thus potentially operate more forcefully on the viewer/user in the service of engagement with the political claims presented, moving the viewer/ user into broader movements of militant activism.

The subjects of Public Secrets and Points of View move from invisibility to visibility and from lack of a voice to an expansive platform for communication, allowing their affective intensities to be unleashed amidst a move from hidden-ness to open-ness. Though no longer hidden as they had been before, the criminalized bodies of Palestinians living under occupation and incarcerated female prisoners in California examined here are still ensnared within carceral structures. Thus, the relay of affect, in this specific context, resonates with Melissa Gregg and Gregory J. Seigworth's $(2010,1)$ contention that "[a]ffect arises in the midst of in-between-ness ... an impingement or extrusion of a momentary or sometimes more sustained state of relation ...." The sense of in-between-ness certainly applies here, as both occupation and incarceration imply living in a state between life and death, freedom and bondage, humanity and barbarity; bodies that are neither here nor there, existing for a moment and receding. "Affect," they posit, "is in many ways synonymous with force or forces of encounter ..." and "accumulates ... becoming a palimpsest of force encounters ..." (Gregg and Seigworth 2010, 2).

The idea of force is directly related to Massumi's (2008) definition of affect as "intensity." Affect, in its emergence and intensity, has two sides, the virtual and the actual:

Affect is this two-sidedness as seen from the side of the actual thing, as couched in its perceptions and cognitions ... the autonomy of affect is its participation in the virtual. Its autonomy is its openness. Affect is autonomous to the degree to which it escapes confinement in the particular body .... (Massumi 2008, 35)

The intensity or force of the encounter, and the affect relayed, is amplified via the accumulation inherent within the interactive documentary form. This form is not structured like an archive or a narrative, but something in-between-cinematic and arranged, though open and interactive. The accumulation of stories, evidence, and testimonies in interactive projects renders visible hidden, yet systemic structures of violence and power through the accumulation of affective encounters with subjects under occupation and incarceration. The affective radicality of the interactive documentary is premised on the logic of amassing. Politically, then, the move from the virtual to the actual and back again referenced by Massumi, based on the perception of the viewer/user, is where the potential for change exists. To feel the affective accumulation and engage the claims of the subjects presented buttressed by a great depth of information, arms the viewer/user with a plethora of affective and effective evidence and knowledge that is acquired in the virtual world to (hopefully) be re-deployed in the actual world. The interactive documentary form engenders an expansive, deep, and transformative witnessing: an affective knowing that demands action. 


\section{Public Secrets}

Public Secrets, created by Daniel and designed by Erik Loyer, was supported by the online journal Vectors: Journal of Culture and Technology in a Dynamic Vernacular in collaboration with Justice Now, an advocacy organization for women prisoners based in Oakland, CA. ${ }^{4}$ The sound portion of the project encompasses the voices of twenty women, interviewed by Daniel at CCWF. Daniel includes nearly six hundred statements displayed algorithmically from the incarcerated women that were recorded over a six-year period (Sharon Daniel 2012, 218). It also includes the sound of a prison cell door clanking shut that marks the transition between sections as the user clicks around the site. The text portion comprises transcriptions of the aforementioned interviews, snippets of text from various cultural, political, and legal theorists such as Giorgio Agamben, Walter Benjamin, Angela Davis, Fredric Jameson, Catherine MacKinnon, and Michael Taussig as well as contextualization from Daniel via excerpts from penal codes, newspapers, and other sources.

The format and design of Public Secrets is intuitive and user friendly. Each section is presented simply as various panes in black, white, and grey marked by large font text displaying a quote from the larger text (either in written or audio form) that awaits the viewer if they choose to click. When one scrolls a mouse over a given pane, it illuminates a blue background, highlighting the section and inviting the viewer to learn more. The bottom right-hand portion of the opening splash screen also provides a link to search the project by topic (i.e., Drug Wars, Alternatives etc.) and a "What You Can Do" link that provides steps toward concrete action, definitions of "decarceration," and links to a host of organizations working in the areas of prison and drug reform.

Part of the impetus for the project stemmed from a media ban enacted by the California Department of Corrections in 1993 in the wake of damning media reports and a slew of lawsuits alleging rampant mistreatment of prisoners. The media ban applies to prisoners who are unable to access computers, cameras, or any other form of media making equipment. It also applies to journalists, academics, and other researchers who are prohibited from conducting face-to-face interviews, using cameras or audio recording devices within the walls of the prison complex, or even using a pen or pencil to record notes on interviews with prison representatives. This near-total blackout of public communication effectively renders the prisoners mute. It shields the public from an accurate representation of what happens to an individual whose crimes are adjudicated with a prison sentence. Daniel gained access to the prisoners as well as the ability to record their thoughts through a legal loophole-prisoners are allowed face-to-face access to "legal advocates" who are able to record their conversations. ${ }^{5}$

The seeming incongruity of the title of the work that melds the oppositional terms "public" and "secret" is a deliberate strategy on the part of Daniel; she writes that:

There are secrets that are kept from the public and then there are "public secrets"—-secrets that the public chooses to keep safe from itself, like the troubling "don't ask, don't tell."The trick to the public secret is in knowing what not to know. This is the most powerful form of social knowledge. Such shared secrets sustain social and political institutions. (Sharon Daniel 2007). ${ }^{6}$

In a basic sense, the public aspect refers to the common perception of the judicial system. In this conception, citizens, either accused of crimes or simply aware that the US legal system begins with the police and ends with adjudication, believe that people "pay back" their debt to society either through fines, community service, or a prison sentence. The secret aspect 
of the title then refers to what happens to the person during the prison sentence, an aspect of the system essentially shielded from public view, especially in California. It also refers to the shielding of the public from the feelings and thoughts of the prisoners. Any appeals they may make to the outside world must emerge from a labyrinth of regulations designed to stultify them. Though we never see the women, the project foregrounds their affectively moving stories, accumulating them to such a degree that they are rendered both typical and overpowering; they transcend the structures that are meant to quell them.

Daniel's choice of title also signals the theoretical conception of the project itself. She structures the viewer/user engagement around the concept of aporia, which she defines as "an irresolvable internal contradiction, between power and knowledge, between information and denial, between the masks of politics and the goals of an open society" (Daniel 2007). The title itself is an aporia, but each section also functions within the same sense of contradiction. Daniel structures the project around three sections: "Inside/Outside," "Bare Life/ Human Life," and "Public Secret/Utopia."These section headings appear (once scrolled over) on the left side of the screen on the initial splash page for the project. Inside/Outside is the most theoretically straightforward of the sections, positing a spatial relation between the space of the prison as existing outside the rules, norms, and guaranteed rights of US citizens living in the world beyond the walls. The conceptions of Bare Life/Human Life draw heavily on the work of Agamben and suggest, as Daniel argues, that

a prisoner ... is reduced from political life to biological life. The prisoner is kept alive, but barely, as naked life-a status that is tautologous with the deprivation of their human rights. Prisoners are thus ideologically acceptable victims of mal-treatment, neglect, and abuse. (Daniel 2006)

Finally, the Utopia aspect of the Public Secret/Utopia section uses Fredric Jameson's conception of the "politics of utopia" (2004), an impulse to foreground utopia when it seems most out of reach within the political imaginary, as well as the work of Angela Y. Davis focused on prison abolition (2003), to theorize both resistance to the prison industrial complex and a world without prisons. Each section contains a selection of audio interviews (with transcripts) from the inmates. When users click the button to "read transcript" during the audio portion, they are also given the option to explore a personalized archive of interviews for that prisoner, allowing for a more complete conception of her thoughts and background. Below, I provide a brief account of the Bare Life/Human Life section to demonstrate how the viewer/user experiences the interface as well as giving a sense of how the various modalities of a section interact with one another and resonate on a political register.

\section{Interacting with aporias Bare Life/Human Life and the aesthetics of politics}

Writing about her aesthetic and design choices for Public Secrets, Daniel contends that:

The interface design constitutes a form of "argument" (as writing does for a scholar), and user navigation functions as a form of "enquiry" (a distillation and translation of the research encounter of the Documentary-maker). $(2012,215)$

The interface itself-the ostensible architecture of the project-exists as a form of argument in its own right, pulling documentary story-telling away from the constraints of linear narrative while melding it with new media, a trend toward a form that is able to better accommodate complexity, varied forms of media, and a multiplicity of voices. In the same vein, the concept of enquiry is a more active form of engagement on the part of the viewer, furthered by the interactive interface. 
In the Bare Life/Human Life section for example, the viewer/user can click on either the Bare Life or Human Life part, with the former occupying the top half of the interface and the latter the bottom. Whichever option is chosen, the screen is divided (in block text) by the phrase "bare life is preserved as an expression of sovereign power," appropriated from Agamben. We are also alerted to the disconcerting notion that a prisoner's body becomes the property of the State of California and is "kept alive to represent state power-to both absorb and reflect state violence-proving that the state has to power to force the prisoner to live under any conditions" (Daniel 2006). This idea and its effects on the psyche of the individual are explored throughout this section.

A prisoner named Jane Dorotik recalls that because the body is state property, women who have been severely sunburned during outdoor activities in the prison have been given "115's," a prison penal code term for disciplinary action that results from defacing state property. Zundre Johnson, another inmate, offers the heartbreaking assessment of life in prison. Recalling the suicide of another inmate's son, she argues that daily life in prison is akin to death: "They do it here every day. They just don't die. That's the cold part. They take their life everyday here ... they just wake up in the morning and kill they self and then function dead." The constraint of only being able to hear their voices and read their words works as an aporia as well. The viewer/user must probe the contradiction of being able to hear but not see the inmates; they exist, but are unseen, alive but not fully embodied.

The wrenching personal stories and testimonies from the inmates in this section are interspersed with texts that underscore the inmate experience and broaden its contextualization by placing their thoughts within the context of wider systemic problems and theoretical discourses (see Figure 1). Daniel provides more quotes from Agamben, further defining

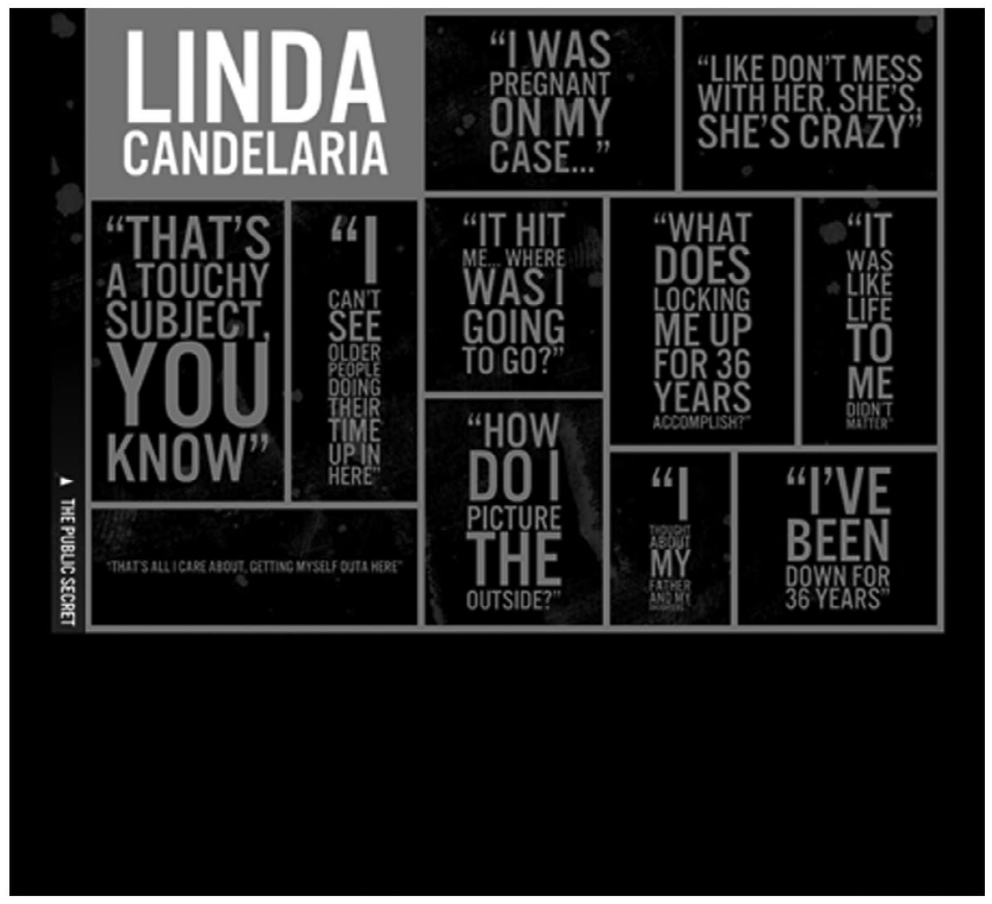

Figure 1. The interface for individual inmates in Public Secrets, courtesy of Sharon Daniel. 
the concept of bare life as well as his concept of homo sacer-the "accursed man" outside the realm of the law (Giorgio Agamben 1998). She also includes an excerpt from the California Code of Regulations (which governs the prison system) that states that a prisoner suicide is considered the destruction of state property. These texts are supported by quotes from a New York Times report on Guantanamo detainees as well as excerpts from the Universal Declaration of Human Rights (UDHR) pertaining to prohibitions against torture and inhuman treatment. The inclusion of these texts serves a number of functions. First, they attest to the validity of the women's testimonies. The punishment for sunburns discussed above, for example, is given added weight by the inclusion of the specific part of the penal code defining ownership of inmate bodies. Second, for inmates who lack basic connections with the outside world, the inclusion of texts on torture and abuse at Guantanamo resonates with the experience of the women, aligning their testimonies and experiences within a global conversation about human rights and detention. Finally, the inclusion of theoretical concepts in concert with the testimonials grounds abstract formulations in concrete, material examples while elevating the voices of the incarcerated women into the realm of academic and political discourse.

Daniel is particularly attuned to the relationship between aesthetics and the political functioning of her work within the context of the interactive documentary. ${ }^{7}$ She turns to French cultural theorist Jacques Rancière's notion of "dissensus," a form of active political confrontation that has the potential for manifestation via art, as a way to theorize her interventions (Jacques Rancière 2010). Daniel argues that the politically informed and motivated interactive documentaries work to:

[materialize] a space of "dissensus" - not a critique, or a protest, but a confrontation of the status quo with what it does not admit, what is invisible, inaudible and othered ... database documentary ... can function as "politics" in Rancière's terms - a politics that I believe has the potential to circumvent the intransigence of the state. (Daniel 2012, 2016)

The confrontation Daniel references is of course immaterial. Notions of the state and the status quo are ideologically-constructed entities with profound material effects on the bodies and lives of those subjugated by them. The political act facilitated by Daniel is the rendering audible, and thus visible in a figurative sense, the subjectivity of the incarcerated women. Their exclusion from society within the space of the prison and its attendant dehumanizing practices, procedures, and regulations strips them of any claim to agency as political subjects with the rights of citizens. The political potentiality in this formulation emerges from the promise of recognition. If the state were to productively engage the (now public) testimonies and claims of the women, it may become more accommodating. But it remains unclear how such practices could circumvent the inflexibility of the state. That said, the logics of amassing and accumulation seen in Public Secrets are not an end in and of themselves, and in some ways, they go beyond Daniel's alignment with Rancière. Rather, the project produces more than simply a "space" of potential politics - it should read as part of an ongoing, larger political movement building consensus and a critical mass of affective and effective evidence for prison abolition. Public Secrets intimately fuses the personal and political, accumulating affective evidence against the un-feeling machinery of the prison industrial complex manifested in California while moving viewers/users into the realm of militant critique, activism, and critical engagement with the prison abolition movement. 


\section{Points of View: mapping Palestinian oppression}

As Gil Hochberg has argued, and much like the women in prison in California, the Israeli control of Palestinian bodies is based on an unequal access to visual rights; Israel maintains a stultifying security state of massive surveillance and the "militarized gaze" of checkpoints and they control what can be seen and heard from within Palestine to the outside world (Gil Hochberg 2015, 1). Points of View is an ongoing interactive project that maps Palestinian video footage created through B'Tselem's Camera Distribution Project (see Figure 2).

B'Tselem was formed in 1989 by a collection of lawyers, journalists, academics, and Knesset members. ${ }^{8}$ The mission of the organization is threefold: to document human rights abuses in Israeli occupied territories in the West Bank and the Gaza Strip; to educate the Israeli public about previously unseen abuses; and to positively affect Israeli policy toward Palestinians through both legal, governmental, and broader media channels. B'Tselem engages in a multi-faceted strategy focused on accountability. In early 2007, B'Tselem added a video advocacy component to their work, initially dubbed "Shooting Back" but which is now known under the less militant name "The Camera Project." To date, the project has distributed cameras to over two hundred Palestinian families, with a particular focus on areas of the Gaza Strip and the West Bank that B'Tselem has identified as most prone to violations.

The logic of the Camera Project is threefold. First, it works as a tool of empowerment for Palestinians, giving civilians the ability to document abuses as they happen, performing a form of "citizen journalism" to produce evidence of abuse in areas unseen by the Israeli media and public, rendering the Palestinian struggle visible. Interestingly, as a side effect of the ubiquity of cameras and their documentations, the camera itself has begun to act as a deterrent for unseemly behavior. Project Director Oren Yakobovich argues that "undoubtedly, when they carry a camera, they suffer less violence, because a camera is a deterrent. There are even some who go around with a broken camera, just so that people won't come near them" (quoted in Haaretz, June 17, 2008). Second, the raw footage captured by Palestinians is turned over to B'Tselem and is re-purposed in varied contexts. At times, it is distributed

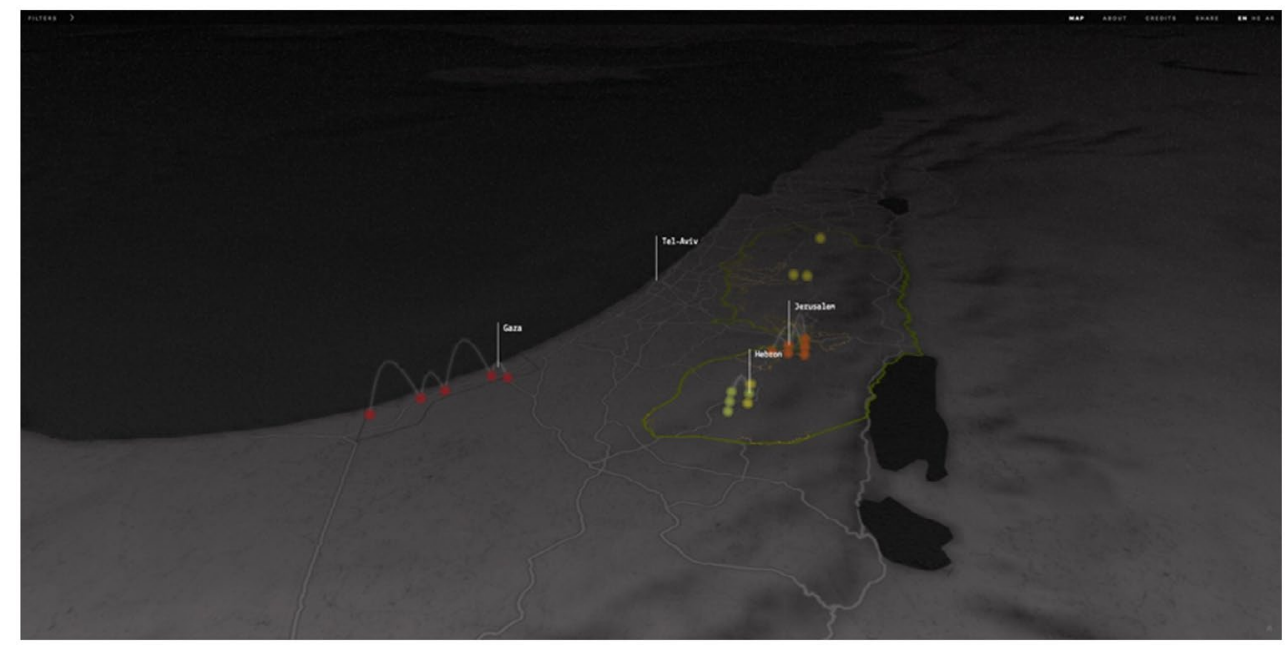

Figure 2. The map interface from Points of View, courtesy of Zohar Kfir. 
to Israeli print and tele-visual media, producing new knowledge for Israeli citizens and policy makers. It is also used as a form of visual evidence in legal complaints filed with Israeli authorities. Finally, the thousands of hours of footage are stored in a vast video archive that is available to the public and utilized by academics, students, filmmakers, and member of the media hoping to glean an affectively forceful perspective of Palestinians living under occupation.

Points of View grew out of Kfir's exploration of B'Tselem's video archive. In a recent interview, she contends that this archive is "comprised of highly complex snapshots, some with violent content and others with testimonies that can be difficult to watch ... it was the type of material that is often stripped of subtlety and dimension when it is inserted into media accounts" (Jenn Linington 2014). Kfir is able to re-inscribe subtlety and dimension through her choice of interface, which is an interactive map of the Israeli-Palestinian territories. She also re-inscribes affect and empathy through her choice of videos and their contextualization through caption and placement on a virtual map featuring the evershifting encroachment of borders of Israel into Palestine. The use of the map quickly allows viewers/users to gain an over-view of the contested region, easily identify various boundaries, and situates the video "nodes" that convey both typicality and pervasiveness. Videos and stories are grouped through "tags" which are a common keyword function used by blogs and other media sites as a way to both organize thematically similar elements and filter out unrelated material. The tags employed by Kfir, which are color coded for easy navigation, are organized by place (i.e., Gaza, East Jerusalem, Hebron, Tel Aviv) and theme (settlers, violence, IDF, youth, women). The initial places, themes, and corresponding videos that comprise the map were chosen through a direct collaboration between Kfir and the archivists in B'Tselem's video department.

The interface allows the viewer/user to click on multiple filters at once to refine their engagement with the site while spatially locating the chosen places and themes on the map. Viewers/users also have the option to click nodes around the site to follow various video trails that are connected by a given tag. Whether the viewer/user engages with just the tags of interest or follows the predetermined trails, the experience is decidedly non-linear and speculative. Kfir provides the literal and figurative "map" that structures the videos and their various contexts. But it is the viewer/user who both creates a narrative through their interaction with various threads of experience and makes meaning from those threads in a way that is open-ended and only partially guided.

Points of View is also open-ended in terms of its technological architecture. Kfir views the project as ongoing and not a fixed media object. She argues, in the aforementioned interview with idocs.org, that "the platform was designed to sustain hundreds of videos" and she hopes that it will grow to function as a "curated archive" of much of B'Tselem's acquired footage while becoming both an "interactive web documentary as well as a platform for research and teaching." To these ends, Kfir designed the project with an open source model, a form of production and development that promotes access (via a free license) to the "backend" of a sites' design. ${ }^{9}$ In other words, Kfir continues to partner with B'Tselem and other groups and individuals by providing access that enables users to upload their own content within the interactive map structure. This structure strategically deploys the B'Tselem footage while providing viewers/users with contextualized, locative snapshots of the Palestinian experience in a way far more enriching and affectively impactful than simply watching one video or one traditional documentary. The affective force of the project on the viewer/user is located in 
two main components: the accumulation of evidence that speaks to the pervasiveness of the occupation that elicits empathy, and the accumulation of practices of militant resistance that elicits hope and solidarity.

The Gaza section of the map ("Gaza-An Inside Look"), for example, contains a video trail comprised of five separate videos. Kfir organizes this section by the tags "Gaza" to denote where the videos where shot and "youth" to designate that videos were made mostly by students. The Gaza video selected grows out of the aftermath of the Gaza War also known as Operation Cast Lead, an armed conflict between Israel and Palestinians residing in the Gaza Strip. The conflict began on December 27, 2008 and lasted until January 18, 2009. According to the official Israeli line, Operation Cast Lead was an effort to stop rocket attacks originating in the Palestinian sections of Gaza. During the conflict, Israeli Defense Forces (IDF) unleashed a multi-front assault, bombing Palestinian homes and assets from the air and sea as well as launching a comprehensive ground invasion and a blockade of the entire Gaza Strip. The conflict resulted in the widespread destruction of property, homes, and the deaths of thousands of Palestinian citizens. Shortly after the hostilities ceased, B'Tselem provided cameras to fifteen university students who were beginning their studies in fields such as communication and journalism, and asked them to film their everyday lives in the wake of the aforementioned destruction.

When the viewer/user scrolls over one of the five nodes placed on the map where the videos were made, an information pane drops down from the left-hand side of the screen informing the viewer/user of the title of the film, the name of the videographer (if known), the tags attributed to the video as well as a brief summary of the context in which the videos were shot. In the case of the Gaza section, Kfir provides a brief description of B'Tselem's efforts in the wake of Operation Cast Lead. The Gaza section includes the videos Tunnel Youth (Unspecified Director, 2009), Summer Games (dir. Fadi al-Ghorra, 2009), War Games (dir. Muhammad al-Aloul, 2009), Hip Hop Lessons (dir. Muhammad al-Majdlawi, 2009), and Making Sand out of Ruins (Unspecified Director, 2010).

In the short video Tunnel Youth (two minutes), we are transported inside a dark, dank looking tunnel (one of many) under the Gazan town of Rafah that is being reinforced and maintained by a group of Palestinian boys that appear to be between fourteen and seventeen years old (see Figure 3 ).

In her description of the video, Kfir notes that the boys spend many long hours each day working in these tunnels, having left school for this work in order to support their families. The tunnel serves as a conduit for food, medicine, and weapons to be transferred among Palestinians in Gaza away from the view of IDF soldiers and outside the ever shifting legal constraints of the Israeli embargo policy. The opening shots of the video reveal the boys wearing headlamps, operating a winch, smoking, and laughing with one another. The popular Palestinian song "Heroes of the Tunnels" plays with a muffled, tinny sound through one of the boys' cellphones, serving as a makeshift, diegetic soundtrack for the entirety of the video.

Following the initial sequences, the cameraman interviews the boys, engaging them on how and why they decided on this dangerous, claustrophobic job. One boy, filmed closely to emphasize the small space of the tunnel, succinctly states: "There's no work elsewhere, so we have to work here," which underscores the profound lack of economic opportunity in an area walled in, cut off, and facing possible destruction at a moment's notice. Another reinforces this idea contending that: "All the crossings are closed; we have to work here." He 


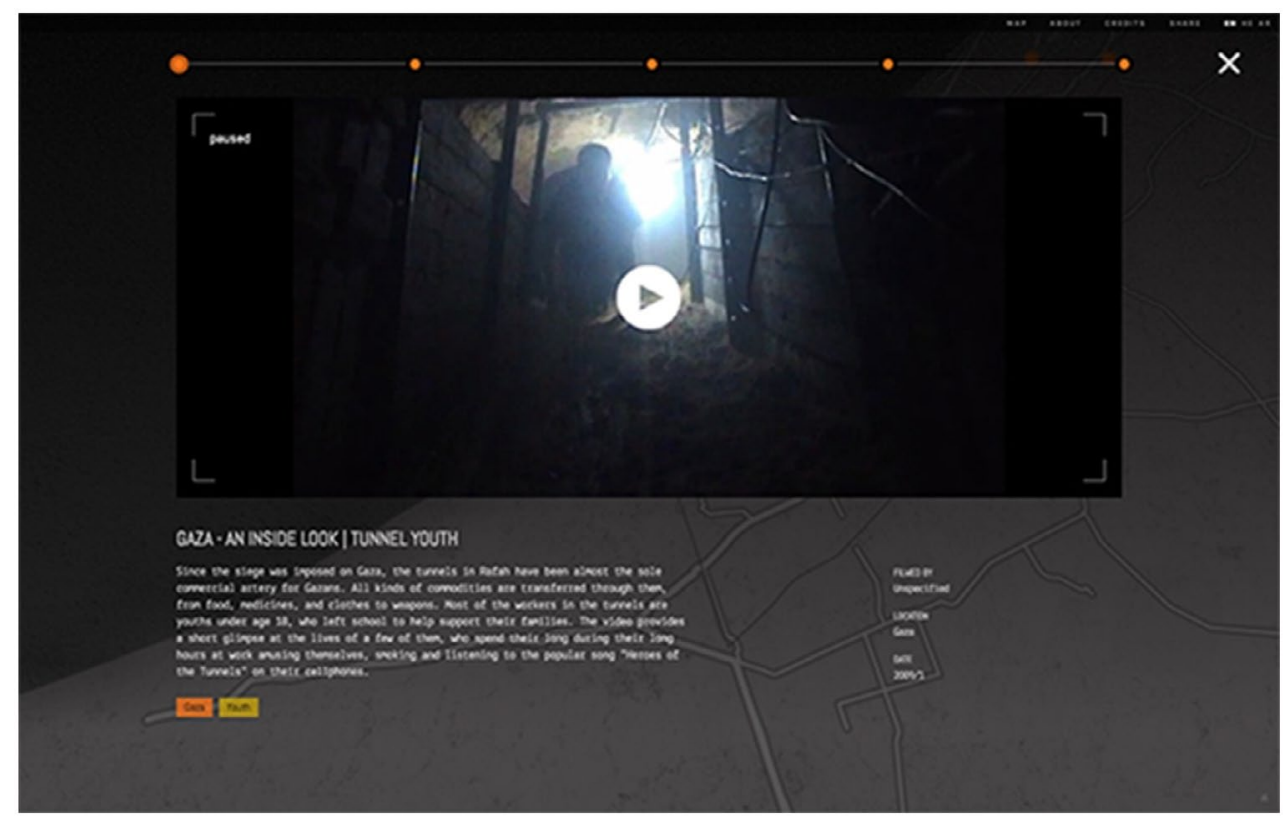

Figure 3. Tunnel Youth video and description, courtesy of Zohar Kfir.

is referencing the plethora of checkpoints (arteries into Israel where the economy is healthy) that had been blockaded in the aftermath of Operation Cast Lead. Yet another boy sums up the precarious situation: "our lives here ... we pray before we go down (into the tunnel)."The boys face the threat of the tunnel closing in on them, and are only able to receive liquid sustenance (water and milk) through a pipe that leads outside the tunnel. Their only contact with the outside is through the use of walkie-talkies. The boys depicted, whose faces are blurred to protect their identities, are covered in dirt, emaciated, and almost feral. The baseness of their existence is shocking and underscores the Palestinian plight in Gaza.

Other sections of the map, East Jerusalem and Hebron for example, follow a similar structure to the Gaza section, albeit with different themes. The Hebron section, comprised of four videos, follows a video trail of clashes between Palestinian residents of Hebron, IDF forces, and Israeli settlers between 2010 and 2012. A particularly disturbing video Officer Head-butts Palestinian, Youth (dir. Zidan Sharabati, 2012) is shot surreptitiously from an apartment above an IDF check point near the Beit Hadassah settlement in Hebron City Center. The video depicts the harassment, brutal beating, and eventual arrest suffered by seventeen-year-old Thair Ghanam at the hands of an IDF soldier. Whereas the Gaza section provided a glimpse into aspects of everyday life involving work, play, and culture, the Hebron section focuses on facets of everyday life that involve unremitting violence, checkpoints, and the encroachment of Israeli settlers as well as the unyielding, often non-violent, practices of resistance on the part of the Palestinians protecting their land. This set of videos, shot as part of the broader Camera Distribution Project, fits squarely into the evidentiary mode and exemplifies the types of videos deployed by B'Tselem in legal proceedings, but as deployed by Kfir, work as affective evidence targeted at the viewer/user.

Kfir's project re-casts these videos as a part of a broader effort to visualize and grasp a broad view of the occupation, while rooted in a variety of specific affective appeals. "Affect," 
Kathleen Stewart argues, "is the promise, or threat, that something is happening-something new, emergent, capable of impact" $(2003,431)$. The invocation of two seemingly opposite ideas, that of a promise and a threat, the former which implies trust and reciprocity and the latter a wielding of a form of power, is particularly apt in regard to Points of View. The promise Stewart mentions exists between Kfir and the subjects represented, an implied assurance to represent their thoughts, actions, and feelings accurately; while the threat emerges from the collection and critical mass of these witnesses and testimonies and their inherent challenge to power. As examined above, depending on the specific context, these appeals vary from intense empathy for the boys stuck in the tunnel, to disgust and outrage over the treatment of everyday Palestinian people at the hands of the IDF, and toward solidarity with practices of resistance. This diversity of appeals works to affect the viewer/ user on many levels of engagement, while orienting them to the larger, militant critique of the occupation. Points of View, much like Public Secrets, offers the viewer/user a different form of knowing, one that is endowed with affectivity to buttress and amplify the mass of effective evidence presented. The impact, force, and affective radicality of Kfir's project will only increase as more videos and points on the map are added in the coming years.

\section{Conclusion}

The two interactive documentaries examined in this essay present a new form or mode of radical documentary practice. Public Secrets and Points of View seek to intervene in political and social struggles by rendering visible usually hidden or "unseen" subjects and carceral structures while providing a platform for the representation of marginalized and disenfranchised groups. The projects also rely heavily on concepts of witness, testimony, and the cultivation of affective identification with both individual subjects and systemic, seemingly intractable injustices. The use of new media technology, as deployed in these projects, enhances the political power of the documentary form by providing an interface and design architecture for the dissemination of vast archives of information, media, images, and perspectives that more traditional forms are unable to accommodate. It also situates documentary projects within global networks and political causes, allowing wide access to participate, learn, and interact; a networked hub capable of reaching, engaging, and activating the collaboration of a global cadre of viewers/users.

Both Public Secrets and Points of View are indebted to partnerships with larger organizations involved in social and political justice struggles. These projects effectively augment their advocacy, serving as one of many means of potential political engagement. Thinking back for a moment to Gregg and Seigworth's $(2010,1)$ idea of an affective encounter as a "momentary or sometimes more sustained state of relation," we see how these projects operate on both an affective and political level. During their engagement with either Public Secrets or Points of View, viewers are immersed within a momentary affective relation with the corpus of subjects presented, as well as the larger systemic critique. It is left up to the viewer whether or not they are sufficiently moved to click and explore beyond the project, to turn their engagement outward and to sustain their relation to the encounter-from personal movement to mass movement.

Whereas these projects certainly expand the form, distribution, and reception of documentary, no single interactive project is a panacea or will single-handedly change the world. 
Rather, they should be seen as politically engaged, documentary-based art forms that are beginning to reflect an emerging and growing global solidarity, in concert with the increased documentation of and mass of evidence of abuse, against systematic forms of oppression. Thus, affective radicality functions within the logic of amassing: myriad encounters beget empathy, information, evidence, imbrication within existing networks of militant activists, and ideally, the beginning of sustained mass movements.

\section{Notes}

1. http://zzee.net/wordpress/ (artist site); http://points-of-view.net/ (project site). http://www.sharondaniel.net/ (artist site); www.publicsecret.net (project site).

2. It has variously been dubbed, "database documentary," "participatory documentary," "web documentary,"'interactive documentary," i'i-docs," "cross-media documentaries," and "docuwebs."

3. See Bhaskar Sarkar and Janet Walker's (2010) recent edited collection Documentary Testimonies: Global Archive of Suffering.

4. See http://www.jnow.org/. California has seen the largest expansion of prisons and mass incarceration in the United States in the past 70 years. See Ruth Wilson Gilmore's (2007) Golden Gulag: Prisons, Surplus, Crisis, and Opposition in Globalizing California.

5. Because she partnered with Justice Now, Daniel was able to have the group designate her as such an advocate and allowed her access, though she must still abide by what she terms "Kafkaesque regulations" as well as invasive search procedures and surveillance of her conversations.

6. Daniel appropriates the term "public secrets" from Michael Taussig. See Michael Taussig (1999).

7. Daniel prefers the term "database documentary" to describe her work.

8. "B'Tselem in Hebrew literally means 'in the image of', and is also used as a synonym for human dignity. The word is taken from Genesis 1:27 'And God created humans in his image. In the image of God did He create him.'It is in this spirit that the first article of the Universal Declaration of Human Rights states that 'All human beings are born equal in dignity and rights."' See http://www.btselem.org/about_btselem

9. The project uses custom coded versions of the applications Python, HTML 5, and WebGL.

\section{Acknowledgements}

I wish to thank Jennifer Black, Amanda Caleb, Domi Olivieri, George Shea, Melanie Shepherd, Margot Wielgus, Glenn Willis, Marta Zarzycka, and the two anonymous reviewers for a wealth of insightful feedback on earlier drafts.

\section{Disclosure statement}

No potential conflict of interest was reported by the author.

\section{Notes on contributor}

Ryan Watson is an Assistant Professor of Film and Visual Media in the Department of Fine Arts at Misericordia University in Dallas, PA. His previous writing has appeared in Afterimage, Animation Journal, InVisible Culture, and the Journal of Film and Video. He is currently finishing a book manuscript titled Militant Evidence: Witness, Archive, and the Radical Documentary in the Age of New Media. E-mail: rwatson@misericordia.edu 


\section{ORCID}

Ryan Watson (iD http://orcid.org/0000-0003-1520-5546

\section{References}

Agamben, Giorgio. 1998. Homo Sacer: Sovereign Power and Bare Life. Translated by Daniel Heller-Roazen. Stanford, CA: Stanford University Press.

Cohen, Hart. 2012. "Database Documentary: From Authorship to Authoring in Remediated/Remixed Documentary." Culture Unbound 4: 327-346.

Daniel, Sharon. 2006. "The Public Secret: Information and Social Knowledge." Intelligent Agent 6 (2). http://www.intelligentagent.com/archive/Vol6_No2_community_domain_daniel.htm

Daniel, Sharon. 2007. "Public Secrets: Authors Statement." Vectors: Journal of Culture and Technology in a Dynamic Vernacular 2 (2). http://vectors.usc.edu/projects/index.php?project=57\&thread= AuthorsStatement

Daniel, Sharon. 2012. "On Politics and Aesthetics: A Case Study of Public Secrets and Blood Sugar." Studies in Documentary Film 6 (2): 215-227.

Davis, Angela Y. 2003. Are Prisons Obsolete? New York: Seven Stories Press.

Davis, Angela Y. 2016. Freedom is a Constant Struggle: Ferguson, Palestine, and the Foundations of a Movement. Chicago, IL: Haymarket Books.

Gilmore, Ruth Wilson. 2007. Golden Gulag: Prisons, Surplus, Crisis, and Opposition in Globalizing California. Berkeley: University of California Press.

Gaines, Jane, and Michael Renov, eds. 1999. Collecting Visible Evidence. Minneapolis: University of Minnesota Press.

Gaines, Jane. 2007. “Documentary Radicality." Canadian Journal of Film Studies 16 (1) Spring: 5-24.

Gaines, Jane. 1999. "Political Mimesis." In Collecting Visible Evidence, edited by Jane Gaines and Michael Renov, 84-102. Minneapolis: University of Minnesota Press.

Gregg, Melissa, and Gregory J. Seigworth, eds. 2010. The Affect Theory Reader. Durham, NC: Duke University Press.

Hochberg, Gil. 2015. Visual Occupations: Violence and Visibility in a Conflict Zone. Durham, NC: Duke University Press.

Jameson, Fredric. 2004. "Politics of Utopia." New Left Review 25: 35-54.

Linington, Jenn. 2014. "Points of View: Putting Occupied Territories on the (Interactive) Map." $i$-Docs.org. http://i-docs.org/2014/09/10/points-of-view-putting-occupied-territories-on-the-interactive-map/

Manovich, Lev. 2001. The Language of New Media. Cambridge: MIT Press.

Massumi, Brian. 2008. “The Thinking-Feeling of What Happens." Inflexions 1 (1): 1-40.

Miles, Adrian. 2014. "Interactive Documentary and Affective Ecologies." In New Documentary Ecologies: Emerging Platforms, Practices and Discourses, edited by Kate Nash, Craig Hight and Catherine Summerhayes, 67-82. New York: Palgrave Macmillan.

Odorico, Stefano. 2011. "Documentary on the Web between Realism and Interaction. A Case Study: From Zero - People Rebuilding Life after the Emergency (2009)." Studies in Documentary Film 5 (2 \& 3): 235-246.

Rancière, Jacques. 2010. Dissensus: On Politics and Aesthetics. Translated by Steven Corcoran. London: Continuum.

Sarkar, Bhaskar, and Janet Walker, eds. 2010. Documentary Testimonies: Global Archives of Suffering. New York: Routledge.

Stewart, Kathleen. 2003. "Arresting Images." In Aesthetic Subjects, edited by Pamela R. Matthews and David McWhirter, 431-448. Minneapolis: University of Minnesota Press.

Taussig, Michael. 1999. Defacement: Public Secrecy and the Labor of the Negative. Stanford, CA: Stanford University Press.

Vertov, Dziga. (1926) 1984. "The Factory of Facts." In Kino-Eye: The Writings of Dziga Vertov, edited by Annette Michelson. Translated by Kevin O'Brien, 58-60. Berkeley: University of California Press.

Waugh, Thomas. 1984. "Introduction: Why Documentary Filmmakers Keep Trying to Change the World or Why People Changing the World Keep Making Documentaries." In Show Us Life: Toward a History and Aesthetics of the Committed Documentary, edited by Thomas Waugh, xi-xxvii. Metuchen, NJ: Scarecrow Press. 